\title{
Asas Penghargaan Terhadap Hak Berpendapat Anak: Pengejawantahan ke dalam Pengajaran dan Pembelajaran
}

\author{
Rika Saraswati \\ Fakultas Hukum dan Komunikasi, Unika soegijapanata Semarang \\ rikasaraswati@unika.ac.id
}

\begin{abstract}
The principle of the rights of the child to be heard is one of the principles on the Convention on the Rights of the Child and Indonesia Child Protection Act. The principle is the content of Hukum Perlindungan Anak (Child Protection Law) as a subject on Law curriculum at School of Law, Faculty of Law and Communication, Soegijapranata Catholic University. The implementation of this subject is an academic responsibility in order to transfer new knowledge and values dealing with the rights of the child and to protect children from all of forms of discrimination and violence. The process of transferring knowledge and values has been undertaken by lecturer and students through three main activities, namely teaching, doing research and doing community service.
\end{abstract}

Keywords: The rights of the child to be heard, teaching, learning

\begin{abstract}
Abstrak
Asas penghargaan terhadap hak berpendapat anak adalah salah satu asas di dalam Konvensi Hak Anak dan UU Perlindungan Anak yang menjadi bagian pokok bahasan mata kuliah Hukum Perlindungan Anak. Penyelenggaraan mata kuliah ini merupakan tanggungjawab akademisi tenaga pengajar di program studi Ilmu Hukum di Unika Soegijapranata dalam melakukan transfer pengetahuan dan nilai terhadap hak-hak anak yang baru untuk mengubah konsep dan nilai-nilai yang salah dan sudah usang dalam memandang anak di mana konsep dan nilai yang ada selama ini telah melanggengkan diskriminasi dan kekerasan terhadap anak. Proses pembelajaran mata kuliah ini melibatkan dosen dan mahasiswa melalui kegiatan pengajaran, penelitian dan pengabdian.
\end{abstract}

Kata kunci: Hak Berpendapat Anak, Pengajaran, Pembelajaran

\section{PENDAHULUAN}

Tulisan ini akan membahas penerapan asas penghargaan terhadap hak berpendapat anak yang merupakan bagian dari materi mata kuliah hukum perlindungan anak ke dalam proses pembelajaran dan pengajaran yang dilakukan oleh dosen pengampu bersama dengan para mahasiswa dalam rangka melakukan transfer pengetahuan, nilai dan pengalaman berkaitan dengan hak-hak anak yang terwujud ke dalam tri dharma perguruan tinggi, yang meliputi 
pendidikan dan pengajaran, penelitian dan pengabdian pada masyarakat.

Keberadaan mata kuliah hukum perlindungan anak merupakan bentuk kepedulian dan tanggung jawab masyarakat akademis sebagaimana yang diamanatkan oleh Undang-Undang Perlindungan anak. Upaya pemenuhan hak-hak anak pada prinsipnya menjadi tanggungjawab negara peserta dalam hal ini Pemerintah Indonesia sebagaimana diamanatkan oleh Konvensi Hak Anak yang telah diratifikasi oleh Pemerintah Indonesia melalui Peraturan Presiden Nomor 36 Tahun 1990, dan selanjutnya memunculkan UU Perlindungan Anak pada tahun 2002 .

Upaya pemenuhan hak-hak anak perlu melibatkan unsur masyarakat, termasuk perguruan tinggi, agar dapat berlangsung dengan baik. Keterlibatan masyarakat di perguruan tinggi belum secara eksplisit muncul di dalam UU Nomor 23 Tahun 2002 tentang Perlindungan Anak. Akan tetapi, keterlibatan masyarakat semakin dipertegas di dalam Pasal 25 UU Nomor 35 Tahun 2014 tentang Perubahan UU Nomor 23 Tahun 2002 tentang Perlindungan Anak yang menyatakan bahwa: "Kewajiban dan tanggung jawab Masyarakat terhadap Perlindungan Anak dilaksanakan melalui (1)kegiatan peran Masyarakat dalam penyelenggaraan Perlindungan Anak.(2) Kewajiban dan tanggung jawab Masyarakat sebagaimana dimaksud pada ayat (1) dilaksanakan dengan melibatkan organisasi kemasyarakatan, akademisi, dan pemerhati Anak.".

Melalui ketentuan tersebut terlihat bahwa pemerintah memandang peran strategis kaum akademisi di peruruan tinggi agar dapat lebih berperan dalam mendidik dan mencerdaskan kehidupan bangsa dan memajukan ilmu pengetahuan dan teknologi dengan memperhatikan dan menerapkan nilai humaniora bagi kehidupan bangsa Indonesia yang berkelanjutan sebagaimana dinyatakan di dalam Pasal 4 UU Nomor 12 Tahun 2012 tentang Pendidikan Tinggi bahwa:

Pendidikan Tinggi berfungsi:

a. mengembangkan kemampuan dan membentuk watak serta peradaban bangsa yang bermartabat dalam rangka mencerdaskan kehidupan bangsa;

b. mengembangkan sivitas akademika yang inovatif, responsif, kreatif, terampil, berdaya saing dan kooperatif melalui pelaksanaan Tridharma; dan

c. mengembangkan Ilmu Pengetahuan dan Teknologi dengan memperhatikan dan menerapkan nilai Humaniora.

Atas dasar berbagai peraturan perundang-undangan tersebut maka peran 
program studi ilmu hukum juga menjadi sangat penting karena Konvensi Hak Anak dan UU Perlindungan Anak sangat berkaitan dengan asas, nilai dan norma hukum yang berkaitan dengan nilai humaniora, khususnya yang berkaitan dengan hak-hak anak dan kewajiban orang dewasa memenuhi hak-hak anak dan untuk melakukan perubahan-perubahan sosial di dalam masyarakat.

Perubahan sosial yang diharapkan adalah melalui perubahan paradigma bahwa anak bukan lagi menjadi properti orangtua melainkan seseorang yang bernilai dengan memiliki hak-haknya secara mandiri. Menurut Howe dan Covell (2010) untuk mewujudkan hak-hak anak tersebut maka menjadi kewajiban dan tanggungjawab negara, orang dewasa dan orangtua untuk menyelenggarakan pemenuhan hak-hak tersebut; dan untuk mengubah paradigma tersebut salah satu cara yang dilakukan adalah dengan mengakui dan menghargai hak berpendapat anak yang selama ini tidak pernah didengar dan dihargai oleh orang dewasa.

\section{Pendidikan dan Pengajaran}

Berdasarkan Pasal 1 UU Nomor 12 Tahun 2012 tentang Perguruan Tinggi yang menyatakan bahwa "Pendidikan adalah suatu usaha sadar dan terencana untuk mewujudkan suasana belajar dan proses pembelajaran agar peserta didik secara aktif mengembangkan potensi dirinya untuk memiliki kekuatan spiritual keagamaan, pengendalian diri, kepribadian, kecerdasan, ahlak mulia serta keterampilan yang diperlukan dirinya, masyarakat, bangsa dan negara" maka proses pengajaran dan pembelajaran asas penghargaan terhadap hak berpendapat anak di dalam mata kuliah hukum perlindungan anak di Program Studi Ilmu Hukum Unika Soegijapranata Semarang diharapkan mampu menciptakan manusia Indonesia yang memiliki pengetahuan tentang asas, persoalan-persoalan dan penyelesaian terkait hak-hak anak. Berdasarkan pengetahuan secara teoritis dan praktis maka seluruh civitas akademika, baik dosen maupun mahasiswa, diharapkan dapat menerapkan asas tersebut kepada masyarakat luas yang berada di luar perguruan tinggi.

Dalam Konvensi Hak Anak dan UUPerlindungan Anak, terdapat empat (4) prinsip atau asas sebagai dasar untuk melaksanakan dan menjamin pemenuhan hak-hak anak. Keempat asas tersebut adalah: kepentingan terbaik anak, nondiskriminasi, tumbuh kembang dan penghargaan terhadap hak berpendapat 
anak. Menurut Pasal 2 UUPA dan penjelasannya, asas non diskriminasi adalah asas yang tidak membedakan, membatasi atau mengucilkan anak baik secara langsung atau tidak langsung berdasarkan agama, suku, ras, status sosial, status ekonomi, budaya, jenis kelamin yang dapat mempengaruhi pemenuhan dan perlindungan hak-hak anak; Asas kepentingan terbaik bagi anak adalah asas yang menekankan bahwa dalam semua tindakan yang berkaitan dengan anak yang dilakukan oleh pemerintah, masyarakat, badan legislatif dan yudikatif, kepentingan yang terbaik bagi anak harus menjadi pertimbangan utama; dan Asas hak untuk hidup, kelangsungan hidup dan perkembangan adalah asas yang menekankan bahwa setiap anak mempunyai hak untuk hidup dengan aman, tenteram, damai, bahagia, sejahtera lahir dan batin, serta berhak atas pemenuhan kebutuhan dasarnya untuk tumbuh dan berkembang secara layak, dan hak untuk mencapai standar hidup yang layak bagi perkembangan fisik, mental, spiritual, moral dan sosial anak.

Selanjutnya, yang dimaksud dengan asas penghargaan terhadap pandangan / pendapat anak adalah asas yang memberikan hak kepada anak untuk menyatakan pendapat dalam segala hal yang mempengaruhi anak, meliputi: hak untuk berpendapat, memperoleh pertimbangan atas pendapatnya, hak untuk mendapat dan mengetahui informasi serta untuk mengekpresikan, hak untuk berserikat menjalin hubungan untuk bergabung, dan hak untuk memperoleh imformasi yang layak dan terlindung dari informasi yang tidak sehat.

Asas penghargaan terhadap hak berpendapat anak selalu disampaikan kepada mahasiswa peserta mata kuliah hukum perlindungan anak melalui proses pembelajaran berupa transfer ilmu di dalam kelas dan melakukan pengamatan atau penelitian kecil di lapangan melalui service learning atau problem based learning. Kegiatan tersebut semuanya diakhiri dengan pembuatan tugas yang hasilnya dipresentasikan di dalam kelas dan diseminarkan dengan mengundang stake holders terkait. Melalui dua cara tersebut maka mahasiswa tidak hanya akan mendapatkan teori melainkan juga pengalaman di lapangan selama melakukan pengamatan dan penelitian. Apabila mahasiswa yang bersangkutan tertarik untuk mendalami lebih lanjut topik yang diteliti, maka pengetahuan tentang kondisi yang nyata di dalam masyarakat dapat digunakan oleh mahasiswa sebagai bekal dan bahan untuk 
menulis tugas akhirnya, yaitu skripsi. Hasil dari pembelajaran mata kuliah ini terdapat beberapa mahasiswa yang mengambil skripsi dengan topik asas penghargaan terhadap hak berpendapat anak dikaitkan dengan hak informasi atas pendidikan seksualitas dan reproduksi kesehatan, misalnya penelitian Gracelia (2017) yang menyoroti "Peranan Dinas Pendidikan Kota Semarang dalam Menjamin Pemenuhan Hak Anak atas Informasi Pendidikan Seksual dan Kesehatan Reproduksi." Melalui topik sejenis Anastasia (2018) melakukan penelitian tentang "Hak Siswa Atas Informasi Pendidikan Seksualitas Dan Kesehatan Reproduksi di SMAN 15". Kedua hasil penelitian menunjukkan bahwa hak anak untuk mendapatkan informasi terkait dengan persoalan seksualitas dan kesehatan reproduksi ternyata masih sangat terbatas, padahal informasi tersebut sangat diperlukan tidak hanya untuk mencegah mereka mengalami pelecehan/kekerasan seksual, kehamilan di usia remaja tetapi juga tanggungjawab dan perilaku terkait dengan seksualitas dan kesehatan reproduksi lainnya.

Melalui pembelajaran mata kuliah ini terdapat beberapa mahasiswa yang mengambil skripsi dengan topik yang dikaitkan dengan persoalan hak asuh anak di pengadilan, misalnya penelitian Ivan (2018) tentang "Pemenuhan Hak Anak Untuk Bertemu Dengan Salah Satu Orang Tuanya Setelah Terjadinya Perceraian" dan Yordan (2017) mengenai "Analisis Hak Berpendapat Anak Sebagai Dasar Pertimbangan Hakim untuk Memutuskan Hak Pemeliharaan dan Mendidik Anak dalam Perkara Perceraian. Keduanya melakukan penelitian di Pengadilan Negeri Semarang dan hasil penelitiannya menunjukkan bahwa hak-hak anak untuk didengar pendapatnya belum dilaksanakan sesuai dengan peraturan perundangundangan yang ada. Hal ini terjadi karena baik Hakim maupun orangtua belum memiliki pemahaman yang cukup baik terhadap hak-hak anak, sehingga berpengaruh di dalam pelaksanaannya yang tentunya merugikan kepentingan dan kebutuhan anak untuk didengarkan pendapatnya.

Selain memberikan manfaat kepada mahasiswa yang mengikuti kuliah dan di tugas akhir di dalam menyusun skripsi, kegiatan ini juga membantu dosen pengampu untuk pengayaan materi kuliah di dalam buku ajar atau sebagai bahan materi untuk melakukan penelitian berikutnya. Dengan demikian, dimungkinkan dosen melakukan penelitian dengan melibatkan mahasiswa, 
kemudian mahasiswa melakukan penelitian dengan topik yang sama dengan mendasarkan salah satu perumusan yang ada sebagai judul penelitian mahasiswa tersebut.

\section{Penelitian}

Kegiatan penelitian menjadi salah satu pilar tri dharma perguruan tinggi karena penelitian adalah kegiatan yang dilakukan menurut kaidah dan metode ilmiah secara sistematis untuk memperoleh informasi, data, dan keterangan yang berkaitan dengan pemahaman dan/atau pengujian suatu cabang ilmu pengetahuan dan teknologi. Hasil dari sebuah penelitian tidak hanya berguna bagi kemajuan perguruan tinggi, khususnya bagi dosen dan mahasiswa, melainkan juga kesejahteraan masyarakat serta kemajuan bangsa dan negara.

Sejak mata kuliah hukum perlindungan terselenggara pada tahun 2007, dosen pengampu telah melakukan banyak penelitian yang terkait dengan permasalahan anak di bidang hukum keperdataan, kepidanaan dan kenegaraan (V. Hadiyono dan Rika Saraswati, 2006; Rika Saraswati dkk, 2007; V.Hadiyono dan Rika Saraswati, 2008; Rika Saraswati dan B. Resti Nurhayati, 2008; V.Hadiyono, Marcella Elwina S,dan B.
Resti Nurhayati, 2013; Rika Saraswati dan V. Hadiyono, 2015).

Dalam kaitannya dengan asas penghargaan terhadap hak berpendapat anak, dosen pengampu juga telah melakukan beberapa penelitian terkait, yaitu mengenai hak anak untuk didengarkan dalam membuat tata tertib sekolah anti-bullying. Rika Saraswati dan V. Hadiyono (2015, 2016) melakukan penelitian di sepuluh sekolah menengah atas di Kota Semarang. Penelitian ini bertujuan untuk melibatkan siswa dan guru untuk bersama-sama membuat suatu tata tertib sekolah yang diharapkan dapat diadopsi ke dalam tata tertib sekolah masing-masing, khususnya yang mengatur tentang bullying. Pelibatan siswa untuk duduk bersama dengan guru karena hak anak untuk berpendapat jarang diberi wahana dan didengarkan oleh para guru. Hasil penelitian ini oleh V. Hadiyono dan Rika Saraswati (2016) juga telah diseminarkan melalui seminar internasional yang diselenggarakan di Malaysia pada tahun 2016 dan dimuat di proseding seminarnya.

Selanjutnya, dosen pengampu juga telah melakukan penelitian tentang hak berpendapat anak bersama mahasiswa di pengadilan. Penelitian V. Hadiyono dan Rika Saraswati (2016) ini dilakukan untuk 
mengetahui sejauh mana hak anak untuk berpendapat didengarkan oleh orang dewasa atau pemerintah ketika orangtua mengajukan permohonan perceraian dan di antara kedua pihak tersebut mengajukan hak asuh atas anak/anakanaknya melalui pengadilan. Kemudian Yordan (2017) melakukan penelitian untuk penulisan skripsi sebagai tugas akhirnya dan skripsi ini merupakan bagian dari penelitian yang dilakukan bersamasama dengan dosen. Penelitian ini bertujuan untuk mengetahui langkah yang dilakukan oleh hakim untuk menetapkan hak asuh anak dan kepada siapa anak akan tinggal dikaitkan dengan kewajibannya untuk mendengarkan pendapat anak sebagaimana yang telah diatur oleh Undang-Undang Perlindungan Anak. Hasil penelitian ini telah dipublikasikan melalui seminar internasional di Malaysia melalui makalah berjudul The Best Interest of The Child: How Are Children Heard in Family Law Proceeding in Indonesia? (Rika Saraswati dan V. Hadiyono, 2018).

Kemudian, penelitian hak berpendapat anak tentang cyberbullying dilakukan oleh Rika Saraswati, Anton Maria Laot Kian, Emanuel Boputra dan Silvidan (2017). Penelitian ini dilakukan di beberapa sekolah menengah atas di
Kota Semarang yang bertujuan untuk mengetahui pemahaman siswa-siswi sekolah tentang cyberbullying dan aspek hukum cyberbullying. Penelitian ini dilakukan karena pendapat anak mengenai cyberbullying ditinjau dari aspek hukum masih jarang dilakukan karena kebanyakan penelitian yang dilakukan di Indonesia lebih menekankan pada perilaku korban ditinjau dari aspek psikologis (Triantoro Safaria, Fatwa Tentama, Hadi Suyono, 2016). Selain itu, penelitian ini juga untuk mengetahui pengalaman mereka dalam menghadapi dan menyikapi cyberbullying .

Selanjutnya, Rika Saraswati, Emanuel Boputra dan Yuni Kusniati (2018) melakukan penelitian yang sedang berlangsung mengenai hak berpendapat anak di dalam sistem hak asuh tunggal dan hak asuh bersama. Penelitian ini bertujuan untuk mengetahui sejauh mana pengadilan dan orangtua yang telah bercerai mendengarkan keinginan anakanaknya, tentunya melalui pendapat atau pandangan mereka, untuk bertemu dengan salah satu orangtua yang tidak mendapatkan hak asuh setelah adanya penetapan pengadilan. Hak anak perlu didengarkan karena hak-hak mereka selama ini terabaikan sebagai akibat penetapan hak asuh tunggal yang selama 
ini ditetapkan oleh hakim di pengadilan, baik Pengadilan Agama maupun Pengadilan Negeri.

Berbagai penelitian dan hasilnya tersebut tidak hanya memperkaya pengetahuan bagi dosen pengampu dalam menyampaikan materi terkait, melainkan juga menjadi titik tolak untuk mengadakan penelitian lanjutan dan memperkaya buku ajar, modul ataupun di dalam pembuatan rancangan pembelajaran semester (RPS). Penelitian yang dilakukan oleh dosen pengampu juga memberi kesempatan kepada mahasiswa untuk terlibat di dalamnya. Saat ini sudah ada upaya dari dosen pengampu untuk melibatkan mahasiswa dalam penelitian yang dilakukan dosen, tidak hanya sebagai pencari data melainkan juga melakukan penelitian untuk penulisan skripsi dengan mengambil salah satu perumusan masalah yang dilakukan oleh dosen pengampu sebagaimana telah dinyatakan sebelumnya dalam sub bab pendidikan dan pengajaran.

\section{Pengabdian}

Mengingat pemenuhan hak-hak anak merupakan persoalan yang dihadapi oleh masyarakat umum maka kegiatan pengabdian yang dilakukan oleh Program Studi Ilmu Hukum dapat dikaitkan dengan persoalan ini. Sebelum tahun 2018, beberapa kegiatan pengabdian dengan tema hak-hak anak ada dua yaitu perundungan/bullying di sekolah dan hakhak anak dan kekerasan dalam rumah tangga. Pada kegiatan yang pertama, program studi Ilmu Hukum bermitra dengan SMA St. Louis untuk penyampaian materi antibullying kepada seluruh siswa di kelas $\mathrm{X}$ hingga XII dengan melibatkan mahasiswa yang pernah mengikuti mata kuliah hukum perlindungan anak ataupun mereka yang tertarik sebagai fasilitator dengan dosen pengampu dan dosen lain yang berminat untuk menjadi pendamping dan telah mendapatkan pelatihan terlebih dahulu. Kegiatan pengabdian yang kedua dilakukan di Desa Gemawang, Kabupaten Semarang. Dalam kegiatan ini cakupan masyarakat yang dituju tidak hanya masyarakat sekolah di sekolah dasar dengan topik pehak-hak anak dan perundungan/bullying, melainkan juga masyarakat umum karena topik yang disampaikan tentang kekerasan anak di dalam rumah tangga. Metode kegiatan pengabdian yang dilakukan sama dengan kegiatan pengabdian yang pertama.

Kemudian pada tahun 2017 dan 2018, kegiatan pengabdian yang dilakukan adalah bekerjasama dengan lembaga KITA. Lembaga ini adalah lembaga yang 
bergerak di bidang pemberdayaan buruh migran dan keluarga yang ditinggalkan di desa Tempuran Dhuwur, Kabupaten Wonosobo. Kabupaten Wonosobo adalah salah satu kabupaten yang angka pernikahan anaknya sangat tinggi di Provinsi Jawa Tengah (M. Abdul Rohman, 2018). Salah satu faktor penyebab dan penyumbang angka pernikahan anak yang tinggi karena menjadi buruh migran. Selain persoalan perkawinan anak, desa ini juga mengalami persoalan dalam memberikan perlindungan hukum, sosial dan ekonomi bagi para buruh migrannya dan keluarga yang ditinggalkan. Oleh karena itu, untuk menjamin perlindungan para buruh migran yang berasal dari desa tersebut dan keluarga yang ditinggalkan oleh para warganya yang menjadi buruh migran maka lembaga KITA menginisiasi pembentukan peraturan desa tentang perlindungan buruh migran dan keluarganya. Kegiatan pengabdian ini melibatkan dosen pengampu mata kuliah legal drafting dan hukum perlindungan anak. Latar belakang yang mendasari pembuatan peraturan desa Perlindungan buruh migran dan keluarganya karena banyak anak-anak yang ditinggalkan oleh para buruh migran (terutama oleh si ibu) sering tidak bisa berkomunikasi dengan orangtuanya, bahkan haknya untuk mendapatkan informasi tentang keberadaan orangtuanya sering tidak diperoleh karena berbagai faktor baik yang terjadi di tempat kerja orangtuanya di luar negeri maupun di desa tempat tinggal anak dan keluarga yang telah ditinggalkan oleh buruh migran.

Berbagai kegiatan pengabdian yang melibatkan dosen dan mahasiswa bersama-sama sangat memberikan manfaat bagi kedua pihak. Bagi mahasiswa yang bersangkutan, mereka mendapatkan kesempatan untuk berinteraksi dengan masyarakat secara langsung dengan cara menampilkan kemampuannya di bidang akademik melalui penyampaian materi, berdiskusi dan menyelesaikan persoalan yang muncul dalam kegiatan tersebut. Dengan kemampuan yang ada setelah mendapat pembekalan, dan setelah mendapatkan pengalaman tersebut maka mahasiswa menjadi lebih percaya diri.

Bagi dosen atau program studi ilmu hukum, kegiatan ini tentunya tidak hanya merupakan suatu bentuk transfer ilmu kepada masyarakat secara langsung, melainkan juga memberikan jasa pelayanan dalam bentuk pendidikan dan advokasi/pendampingan hukum yang dibutuhkan dalam upaya meningkatkan 
kesadaran hukum masyarakat atas hak-hak anak dengan tujuan untuk menekan atau mengurangi angka kekerasan terhadap anak baik di ranah privat maupun publik Selain itu, kegiatan pengabdian kepada masyarakat merupakan suatu bentuk promosi yang berkelanjutan yang sangat baik bagi program studi Ilmu Hukum secara khusus, dan bagi Fakultas Hukum dan Komunikasi secara umum.

\section{Kesimpulan}

Asas penghargaan terhadap hak berpendapat anak merupakan salah satu asas dalam pelaksanaan pemenuhan dan perlindungan hak-hak anak di Indonesia yang sudah diatur di dalam Konvensi Hak Anak dan Undang-Undang Perlindungan Anak 2002 dan 2014. Agar supaya asas penghargaan terhadap hak anak untuk menyampaikan pendapat/pandangan dan hak mendapat informasi dapat terlaksana dengan baik maka peran perguruan tinggi sangat dibutuhkan karena perguruan tinggi adalah sebuah lembaga yang memiliki peran sangat strategis dalam mencerdaskan bangsa melalui kegiatan pengajaran, penelitian dan pengabdian. Pengejawantahan asas penghargaan terhadap hak anak untuk berpendapat, berpandangan dan mendapatkan informasi telah dilakukan secara terintegrasi melalui kegiatan pendidikan dan pengajaran, penelitian dan pengabdian oleh dosen pengampu, dosen lintas mata kuliah, mahasiswa dan anggota masyarakat lainnya.

\section{DAFTAR PUSTAKA}

Anastasia Anita Carolina Hadi. (2018). Hak Siswa Atas Informasi Pendidikan Seksualitas Dan Kesehatan Reproduksi Ditinjau Dari Pasal 10 Undang-Undang Nomor 23 Tahun 2002 Tentang Perlindungan Anak (Studi Kasus SMAN 15 Semarang). Skripsi S1 tidak dipublikasikan. Unika Soegijapranata, Semarang.

Antonius Maria Laot Kian, Rika Saraswati, Emanuel Boputra, Silvidan. (2017). Cyberbullying dan Aspek Hukumnya: Studi Eksplorasi tentang Pemahaman dan Pengalaman Siswa Sekolah Menengah Atas di Kota Semarang. Hasil Penelitian tidak dipublikasikan. Unika Soegijapranata, Semarang.

Gracelia Retno Alvionita. (2017). Peranan Dinas Pendidikan Kota Semarang Dalam Menjamin Pemenuhan Hak Anak Atas Informasi Pendidikan Seksual Dan Kesehatan Reproduksi Ditinjau Dari Pasal 10 Undang-Undang Nomor 23 Tahun 2002 Tentang Perlindungan Anak. Skripsi S1 tidak dipublikasikan. Unika Soegijapranata, Semarang.

Ivan Ricardo Gitowardjojo. (2018). Pemenuhan Hak Anak Untuk Bertemu Dengan Salah Satu Orang Tuanya Setelah Terjadinya Perceraian Menurut Pasal 14 Ayat (2) UndangUndang Nomor 35 Tahun 2014 (Studi 
Kasus Di Pengadilan Negeri Semarang). Skripsi S1 tidak dipublikasikan. Unika Soegijapranata, Semarang.

M. Abdul Rohman. (2018, April 23) Angka Pernikahan Dini di Wonosobo Masuk Peringkat Tinggi. Suara Merdeka

diunduh dari

https://www.suaramerdeka.com/index .php/news/baca/32186/angka-

pernikahan-dini-di-wonosobo-masukperingkat-tinggi

R. Brian Howe and Katherine Covell. (2010). Miseducating Children about their Rights. Education, Citizenship and Social Justice, 5(2), 91-102.

Rika Saraswati dkk. (2007). Safe School dan Kekerasan Berbasis Jender: Studi Eksplorasi Pada Siswa SMP dan SMA di Kota Semarang. Hasil Penelitian tidak dipublikasikan. Fakultas Hukum dan Komunikasi Unika Soegijapranata, Semarang.

Rika Saraswati dan B. Resti Nurhayati. (2008). Pemahaman Hak Anak dan Safe School pada Siswa Sekolah Dasar dan Guru di Kota Semarang. Hasil Penelitian tidak dipublikasikan. Fakultas Hukum dan Komunikasi Unika Soegijapranata, Semarang.

Rika Saraswati dan V. Hadiyono. (2015). Tata Tertib Sekolah yang Responsif anti Kekerasan/Bullying sebagai Upaya untuk Mewujudkan Pemenuhan Hak-Hak Anak Sekolah di Kota Semarang. Hasil Penelitian tidak dipublikasikan. Fakultas Hukum dan Komunikasi Unika Soegijapranata, Semarang.

Rika Saraswati dan V. Hadiyono. (2016). Tata Tertib Sekolah yang Responsif anti Kekerasan/Bullying sebagai Upaya untuk Mewujudkan Pemenuhan Hak-Hak Anak Sekolah di Kota Semarang. Hasil Penelitian tidak dipublikasikan. Fakultas Hukum dan Komunikasi Unika Soegijapranata, Semarang.

Rika Saraswati dan V. Hadiyono. (2018, April). The Best Interest of The Child: How Are Children Heard in Family Law Proceeding in Indonesia? Konferensi diselenggarakan oleh The Universiti Malaysia Sabah (UMS), Kota Kinabalu, Sabah.

Rika Saraswati, Emanuel Boputra dan Yuni Kusniati. (2018). Membangun Sistem Pengasuhan Anak Dari Pengasuhan Tunggal Menjadi Pengasuhan Bersama Sebagai Perwujudan Pemenuhan Asas Kepentingan Terbaik Anak (Studi Kasus di Pengadilan Agama dan Pengadilan Negeri Semarang). Penelitian sedang berlangsung. Fakultas Hukum dan Komunikasi Unika Soegijapranata, Semarang.

Triantoro Safaria, Fatwa Tentama, Hadi Suyono. (2016). Cyberbully, Cybervictim, and Forgiveness among Indonesian High School Students. The Turkish Online Journal of Educational, 15(3), 40-9.

V. Hadiyono dan Rika Saraswati. (2006). Pertimbangan Hakim dalam Pertimbangan Hakim dalam Putusan Pengadilan tentang Hak Nafkah Anak dalam Kasus Perceraian. Hasil Penelitian tidak dipublikasikan. Fakultas Hukum dan Komunikasi Unika Soegijapranata, Semarang.

V. Hadiyono dan Rika Saraswati. (2008). Kebijaksanaan Pemerintah Kota dalam Mewujudkan Kota Ramah 
Anak. Hasil Penelitian tidak dipublikasikan. Fakultas Hukum dan Komunikasi Unika Soegijapranata, Semarang.

V. Hadiyono dan Rika Saraswati. (2016). Penerapapan Asas Penghargaan Terhadap Hak Berpendapat Anak Dalam Putusan Pengadilan Tentang Hak Pemeliharaan Dan Mendidik Anak ( Studi Kasus Di Pengadilan Negeri Semarang). Hasil Penelitian tidak dipublikasikan. Fakultas Hukum dan Komunikasi Unika Soegijapranata, Semarang.

V. Hadiyono dan Rika Saraswati. (2016, October). Bullying at Schools and Its Prevention through the School Rules (Case Study in Ten Senior High Schools in Semarang, Indonesia), Konferensi diselenggarakan di Subang Jaya, Malaysia.

V.Hadiyono, Marcella Elwina S, dan B. Resti Nurhayati. (2013). Membangun Pranata Peradilan Restoratif Penyelesaian Perkara Anak yang Berkonflik dengan Hukum Pidana, Hasil Penelitian tidak dipublikasikan. Unika soegijapranata, Semarang.

Yordan Febrianto. (2017). Analisis Hak Berpendapat Anak Sebagai Dasar Pertimbangan Hakim Untuk Memutuskan Hak Pemeliharaan Dan Mendidik Anak Dalam Perkara Perceraian (Studi Kasus Di Pengadilan Negeri Semarang). Skripsi S1 tidak dipublikasikan. Fakultas Hukum dan Komunikasi Unika Soegijapranata, Semarang., 